\title{
Traditional Leaders and the 2014-2015 Ebola Epidemic
}

\author{
Peter van der Windt \\ New York University - Abu Dhabi \\ Corresponding author: petervanderwindt@ nyu.edu \\ Maarten Voors \\ Wageningen University and Research \\ maarten.voors@wur.nl
}

25 June 2019

\begin{abstract}
We assess the role of traditional authorities during an acute health crisis, the 2014-2015 Ebola epidemic in Sierra Leone. We exploit plausible exogenous variation in the political competition for local chieftaincy positions and find evidence that traditional leaders helped shape the course of the epidemic. Locations with more "powerful" chiefs experienced substantially fewer recorded Ebola cases. We argue that this result is consistent with a view of traditional authorities as 'stationary bandits', where leaders are locally embedded and thus benefited directly from controlling the spread of the disease. Subsequently, control measures were most effectively implemented by more powerful chiefs.
\end{abstract}

Keywords: Traditional Authority; Ebola Virus Disease; Sierra Leone; Elite Control

Forthcoming in Journal of Politics.

\section{Financial Support}

We gratefully acknowledge funding from the Royal Netherlands Embassy in Ghana, the Netherlands Organisation for Scientific Research (grants \#451-14-001 and \#W08.250.2013.111), the UK's Economic and Social Research Council (grant \#ES/J017620/1) and New York University - Abu Dhabi. 
In many parts of the developing world, the reach of the government beyond the capital is limited and citizens are governed by traditional leaders (e.g. Herbst 2000). These leaders whether chiefs, kings, headmen, queen mothers, councils of elders, and so on - are responsible for domains generally considered the remit of the state, such as public goods provision (Logan 2013), the allocation of land (Goldstein and Udry 2008), and dispute resolution (Mokuwa et al. 2011). Although the role and influence of traditional leaders is "widely accepted as a given" (Logan 2009), existing scholarship comes to varying conclusions about their benefit to society. ${ }^{1}$ Here, we focus on the impact of traditional leaders on socioeconomic development. Recent empirical work shows a positive association between contemporary development and the centralization of precolonial institutions (Michalopoulos et al 2013, Osafo-Kwaako et al 2013). ${ }^{2}$ Other studies focus on contemporary traditional leadership. Acemoglu et al (2014) find that areas with fewer constraints on local chiefs' power, score worse on educational, health and economic outcomes in Sierra Leone. Other studies paint a more positive picture. Diaz-Cayeros et al (2014) show that Mexican communities governed by "traditional" customary law, have better local public goods compared to those governed by "modern" forms of representative government. Goist and Kern (2018) highlight the importance of traditional institutions for the provision of local public goods in Uganda. Baldwin and Mvukiyehe (2015) show that introducing elections into traditional polities may harm public order and the provision of public goods.

\footnotetext{
${ }^{1}$ Holzinger et al (2016) provide a rich review of studies on traditional leadership, the internal organization of traditional politics, and their interaction with democracy, development and public good provision.

${ }^{2}$ See also Englebert (2000) on state capacity in Africa and the influence of precolonial institutions.
} 
We contribute to this literature by assessing the role of traditional authorities in an acute health crisis, the 2014-2015 Ebola epidemic in Sierra Leone. The disease spilled over from neighboring Guinea during May 2014 and subsequently spread rapidly across the country, reaching its peak during December 2014. In November 2015, the WHO declared Sierra Leone to be Ebola free. In total, the country recorded 8,704 laboratory-confirmed Ebola cases and 3,955 deaths (WHO 2016).

There are good reasons to believe that traditional leaders played a central role during the crisis. Sierra Leone comprises 149 Chiefdoms, each governed by a Paramount Chief. These Paramount Chiefs are elected for life by a Tribal Authority that is made up of local notables. Paramount Chiefs have a large influence over society within their Chiefdom as they have considerable autonomy in matters related to raising taxes, the judicial system, and the allocation land (Fanthorpe, 2005). Because Ebola is a social disease that spread through human-to-human contact (Fang et al, 2016), Paramount Chiefs played a potentially important role during the Ebola epidemic. We use data on recorded Ebola incidence in Sierra Leone and combine this with plausibly exogenous variation in the number of families that can stand for the Paramount Chieftaincy to test this claim.

\section{Data and Empirical Strategy}

Our primary outcome is the number of laboratory-confirmed Ebola cases in a Chiefdom. ${ }^{3}$ Data come from laboratory tests of "persons under investigation" reported to the Sierra Leone Ministry of Health and Sanitation between May 2014 and September 2015 (Fang et al, 2016).

Table 1 summarizes our data (variable definitions can be found in Appendix A). On average,

\footnotetext{
${ }^{3}$ We do not have access to actual mortality data, because these data are not available. However, there is a strong correlation between confirmed cases and mortality (45\% of laboratoryconfirmed cases died).
} 
Chiefdoms saw 33 confirmed and 15 suspected Ebola cases. The variation, however, is large; 35 Chiefdoms had no cases, while one Chiefdom (Bombali Sebora) saw 582 cases. Figure B1 in Appendix B illustrates the variation across Chiefdoms.

To capture the "power" of Paramount Chiefs, we follow Acemoglu et al (2014) and use the historical number of ruling houses per Chiefdom. The logic runs as follows. In Sierra Leone, only individuals from "ruling families" within a Chiefdom, identified by British colonial authorities in 1896, are eligible to become Paramount Chiefs. This political system perpetuated after independence. Acemoglu et al (2014) document a direct relation between the number of ruling houses and the concentration of power: Paramount Chiefs in Chiefdoms with more ruling families face more potential challengers, and thus more constraints can be placed on the power of the ruling chief. Importantly, the variation in the number of ruling families is arguably exogenous. The number of ruling families were often the result of historical accident, such as the availability of a male heir or the number of leaders in an invading warring party. We refer to Acemoglu et al (2014) for a careful exposition. Figure B1 in Appendix B illustrates the variation across Chiefdoms, ranging from one to twelve ruling families. In our analyses, we use the variable "Paramount Chief power", which is the inverse of the number of ruling families, for ease of interpretation.

Table 1. Descriptive Statistics

\begin{tabular}{llccccc}
\hline$\#$ & Label & N & Mean & SD & Min & Max \\
\hline 1 & Ebola confirmed cases & 149 & 33.14 & 71.66 & 0 & 582 \\
2 & Number of ruling families & 149 & 3.95 & 2.15 & 1 & 12 \\
3 & Paramount Chief power & 149 & 0.34 & 0.21 & 0.08 & 1 \\
4 & Chiefs recalled & 149 & 5.8 & 2.59 & 1 & 17 \\
5 & Amalgamation & 149 & 0.31 & 0.46 & 0 & 1 \\
6 & Mining permits & 149 & 0.17 & 0.38 & 0 & 1 \\
7 & Distance to coast & 149 & 105.33 & 65.61 & 3.11 & 250.4 \\
8 & Distance to nearest river & 149 & 9.18 & 7.22 & 0.09 & 36.54 \\
9 & Distance to 1895 trade routes & 149 & 20.19 & 19.94 & 0 & 94.87 \\
10 & Distance to 1907 railroad & 149 & 44.19 & 30.34 & 0.06 & 133.79 \\
11 & Minimum distance to major city & 149 & 79.21 & 44.27 & 7.49 & 213.43 \\
12 & Population size in 2004 & 149 & 23819.78 & 16168.52 & 2607 & 87366 \\
\hline
\end{tabular}

Notes: Detailed variable descriptions are in Appendix A. 
We test whether variation in the power of Paramount Chiefs explains the intensity of Ebola across Sierra Leone. Specifically, we estimate:

$$
\operatorname{Cases}_{i}=\alpha_{D}+\beta \text { Power }_{i}+\Gamma C^{\prime}+\varepsilon_{i}
$$

where Cases $_{i}$ refers to the number of confirmed Ebola cases for chiefdom $i$ (log sine transformed to reduce the influence of extreme values). Power $i$ captures the inverse of the number of ruling families in Chiefdom $i . C^{\prime}{ }_{i}$ is a vector that captures Chiefdom level characteristics, which include the number of Paramount Chiefs the oral historians could recall, and whether a Chiefdom was amalgamated. It also includes six historic and geographic factors that may be correlated with traditional leadership and current-day disease environment: presence of mining permits in the 1930s, distance to coast, distance to nearest river, distance to 1895 trade routes, distance to 1907 railroad, and minimum distance to Bo, Kenema, or Freetown. ${ }^{4}$ Finally, $\alpha_{D}$, with $(D=1, \ldots, 12)$, are District specific intercepts to control for any differences between Districts (the 149 Chiefdoms are grouped into 12 Districts) and $\varepsilon_{i}$ is the usual idiosyncratic error term. We thus run the exact same empirical test as Acemoglu et al (2014) albeit changing the dependent variable. We also submit our data to a battery of robustness tests.

\footnotetext{
${ }^{4}$ Note that Acemoglu et al (2014) find a negative relationship between the number of ruling families and two geographic controls: distance from the 1907 railway and distance from the three major towns. As a further robustness check against the possibility that strong chiefs populate remote places and are therefore less affected by Ebola, we use geospatial data and created a Chiefdom indicator of ruggedness following Nunn and Puga (2012). Adding this control produces similar results as those reported in the main text (see Appendix C).
} 


\section{Results}

Table 2 reports our main results (in standardized coefficients). We find strong support for the hypothesis that traditional leaders played a key role in combatting the 2014-2015 Ebola epidemic. Column (1) presents a simple regression without controls. Column (2), our preferred specification, as per model (1), shows that Chiefdoms with a one standard deviation (SD) more powerful Paramount Chief are associated with a 0.18 SD decrease in log Ebola cases $(\mathrm{p}<0.05)$. In substantive terms, this result implies that adding one additional ruling family (i.e. less powerful Paramount Chief) leads to an increase of 22.6\% Ebola cases in that Chiefdom.

In columns (3) to (6), we present results from a set of robustness tests. Column (3) estimates a negative binomial to model Ebola counts, which exhibits overdispersion and excess zeros. Column (4) controls for population size, taking into account that larger Chiefdoms likely saw more Ebola cases (which we confirm). ${ }^{5}$ Column (5) adds a spillover term, i.e. $\sum_{j \epsilon N(i)}$ Cases $_{j}$, capturing the sum of all Ebola events in those Chiefdoms $j$ bordering Chiefdom $i$. Adding this term attenuates concerns about spurious correlations brought about by geographic factors shaping both clusters of chiefly authority and Ebola incidence. We find no evidence for spatial diffusion of Ebola. Finally, to verify whether Ebola incidence is lower even after initial exposure, column (6) presents results for chiefdoms that reported at least one Ebola confirmed case. Throughout the table, the strong effect remains.

A possible alternative explanation for the results presented here is that in Chiefdoms with more powerful traditional leaders, fewer Ebola cases were reported. Christensen et al (2019), for example, find that in areas with engaged and accountable health personnel the number of reported Ebola cases was higher as more patients came forward to be tested. In

\footnotetext{
5 Table D1 in the Appendix D shows that columns (1) - (3) and (5) provide similar results when the dependent variable is rescaled by the chiefdom's population size.
} 
Appendix E, we use additional data from Fang et al (2016) and the nationally representative National Public Services (NPS) survey conducted before the onset of Ebola to show that this is not the case. First, the presence of Ebola response infrastructure via which reporting took place is unrelated to characteristics of the Paramount Chief. Ebola response locations were chosen by the government and international actors based on Ebola incidence. We also find no evidence that Paramount Chiefs govern chiefdoms with more health infrastructure present at the onset of the epidemic. Second, there is no evidence that the power of the Paramount Chief is related to the ability and willingness of citizens to report Ebola cases. Data collected before the Ebola epidemic suggest that citizen use of (government-provided) health facilities was unrelated to the strength of the Paramount Chief. In addition, there is no association between the power of the Paramount Chief and the total number (confirmed plus suspected) of reports. Third, there is also no evidence that the quality of Ebola virus laboratory testing was worse in chiefdoms with more powerful traditional leaders. 
Table 2. Paramount Chief Power and Ebola Cases

\begin{tabular}{|c|c|c|c|c|c|c|}
\hline & $\begin{array}{c}\text { (1) } \\
\text { Basic }\end{array}$ & $\begin{array}{c}\text { (2) } \\
\text { FEs + } \\
\text { Controls }\end{array}$ & $\begin{array}{c}\text { (3) } \\
\text { Neg. Bin. }\end{array}$ & $\begin{array}{c}(4) \\
\text { Population }\end{array}$ & $\begin{array}{c}\text { (5) } \\
\text { Spatial }\end{array}$ & $\begin{array}{c}(6) \\
\text { Exposure }\end{array}$ \\
\hline Paramount & $-0.305^{* * *}$ & $-0.176^{* *}$ & $-0.202^{* *}$ & $-0.154^{* *}$ & $-0.154^{* *}$ & $-0.179^{* *}$ \\
\hline Chief power & $(0.079)$ & $(0.077)$ & $(0.080)$ & $(0.066)$ & $(0.066)$ & $(0.068)$ \\
\hline Chiefs recalled & & $\begin{array}{c}0.047 \\
(0.083)\end{array}$ & $\begin{array}{c}0.025 \\
(0.069)\end{array}$ & $\begin{array}{l}-0.028 \\
(0.071)\end{array}$ & $\begin{array}{l}-0.028 \\
(0.072)\end{array}$ & $\begin{array}{c}0.004 \\
(0.076)\end{array}$ \\
\hline Amalgamation & & $\begin{array}{c}-0.005 \\
(0.093)\end{array}$ & $\begin{array}{c}-0.023 \\
(0.081)\end{array}$ & $\begin{array}{c}-0.038 \\
(0.080)\end{array}$ & $\begin{array}{c}-0.044 \\
(0.082)\end{array}$ & $\begin{array}{c}-0.006 \\
(0.088)\end{array}$ \\
\hline Mining & & $\begin{array}{l}0.124^{*} \\
(0.071)\end{array}$ & $\begin{array}{c}0.098^{*} \\
(0.056)\end{array}$ & $\begin{array}{c}0.061 \\
(0.062)\end{array}$ & $\begin{array}{c}0.059 \\
(0.062)\end{array}$ & $\begin{array}{c}0.055 \\
(0.061)\end{array}$ \\
\hline Coast & & $\begin{array}{c}-0.014 \\
(0.190)\end{array}$ & $\begin{array}{c}0.079 \\
(0.171)\end{array}$ & $\begin{array}{c}0.135 \\
(0.163)\end{array}$ & $\begin{array}{c}0.125 \\
(0.166)\end{array}$ & $\begin{array}{l}0.362^{* *} \\
(0.181)\end{array}$ \\
\hline Nearest river & & $\begin{array}{c}0.070 \\
(0.070)\end{array}$ & $\begin{array}{c}0.055 \\
(0.066)\end{array}$ & $\begin{array}{c}0.032 \\
(0.060)\end{array}$ & $\begin{array}{c}0.031 \\
(0.060)\end{array}$ & $\begin{array}{c}-0.007 \\
(0.066)\end{array}$ \\
\hline Trade route & & $\begin{array}{l}-0.115 \\
(0.107)\end{array}$ & $\begin{array}{l}-0.080 \\
(0.094)\end{array}$ & $\begin{array}{l}-0.147 \\
(0.091)\end{array}$ & $\begin{array}{l}-0.138 \\
(0.095)\end{array}$ & $\begin{array}{c}-0.136 \\
(0.095)\end{array}$ \\
\hline Railroad & & $\begin{array}{l}-0.266^{*} \\
(0.159)\end{array}$ & $\begin{array}{c}-0.258^{* * *} \\
(0.131)\end{array}$ & $\begin{array}{c}-0.279^{* *} \\
(0.136)\end{array}$ & $\begin{array}{c}-0.263^{*} \\
(0.144)\end{array}$ & $\begin{array}{c}-0.217 \\
(0.152)\end{array}$ \\
\hline Major city & & $\begin{array}{l}-0.278 \\
(0.190)\end{array}$ & $\begin{array}{l}-0.214 \\
(0.158)\end{array}$ & $\begin{array}{l}-0.089 \\
(0.164)\end{array}$ & $\begin{array}{l}-0.088 \\
(0.165)\end{array}$ & $\begin{array}{l}-0.202 \\
(0.187)\end{array}$ \\
\hline Population size & & & & $\begin{array}{c}0.448^{* * *} \\
(0.064)\end{array}$ & $\begin{array}{c}0.441^{* * *} \\
(0.067)\end{array}$ & $\begin{array}{c}0.355^{* * *} \\
(0.064)\end{array}$ \\
\hline Ebola neighbors & & & & & $\begin{array}{c}0.033 \\
(0.095)\end{array}$ & $\begin{array}{c}0.032 \\
(0.093)\end{array}$ \\
\hline District FEs & $\mathrm{N}$ & $\mathrm{Y}$ & $\mathrm{Y}$ & $\mathrm{Y}$ & $\mathrm{Y}$ & $\mathrm{Y}$ \\
\hline Regression & OLS & OLS & Neg. Bin. & OLS & OLS & OLS \\
\hline $\mathrm{N}$ & 149 & 149 & 149 & 149 & 149 & 112 \\
\hline $\mathrm{R}^{2}$ & 0.093 & 0.519 & NA & 0.654 & 0.654 & 0.607 \\
\hline
\end{tabular}

Note: Regressions at chiefdom level. All variables are standardized. Standard errors in

$$
\text { parentheses. } * \mathrm{p}<0.10, * * \mathrm{p}<0.05, * * * \mathrm{p}<0.01 \text { (two-tailed). }
$$

\section{Discussion and Conclusion}

We provide evidence for the important role that traditional leaders played during the 20142015 Ebola outbreak in Sierra Leone. Chiefdoms with more powerful Paramount Chiefs saw significantly fewer Ebola cases. Qualitative evidence supports the interpretation that traditional authorities were instrumental in the Ebola response (Richards 2016). 
To understand why Paramount Chiefs undertake anti-Ebola efforts we build on Baldwin (2016). As in other developing countries, Paramount Chiefs in Sierra Leone are embedded in their Chiefdom. Like Mancur Olson's (2000) "stationary bandits", chiefs are dependent on their local economy. Restrictions on travel and thus trade (roadblocks, and even complete quarantines) due to Ebola, led to a de facto shutdown of the local economy, directly curbing income earning opportunities for Paramount Chiefs. Furthermore, in contrast to malnutrition and anemia (cf. Acemoglu et al 2014), Ebola threatened Paramount Chiefs and their families directly. An illustrative example is Paramount Chief Kallon who lost his wife and child to Ebola in the early stages of the disease, and became one of the most actively involved Paramount Chiefs in implementing actions to combat Ebola (Richards 2016).

Qualitative accounts suggest three mechanisms how traditional leaders were able to shape the course of the Ebola epidemic. First, Paramount Chiefs create and enforce so-called traditional "byelaws" (Mokuwa et al 2011). Byelaws introduced during the Ebola epidemic included restrictions on harboring sick people, exclusion of traditional healers from offering treatment and restricting traditional burial practices (see Appendix F). Compliance with these byelaws was enforced by Paramount Chiefs. Second, information campaigns such as: "Do not shake hands", "Report suspected cases", etc, in some places was met with resistance due to distrust in the government (Moran, 2015 Niang, 2014, Faye 2015), leading people to shy away from health facilities (Morse et al, 2016). Paramount Chiefs that enjoy popular support and trust among their citizens can dispel false or conflicting information (e.g. Richards 2016). Third, some Paramount Chiefs organized local response efforts to combat Ebola. For example, Richards (2016) highlights how transmission was slowed by mobilizing young men into antiEbola task forces. Their job was to spread information and teach villagers about the disease risks, find the sick, and raise alarm if needed. Youths also operated as surveillance workers, contact tracers and members of safe burial teams. 
These mechanisms are consistent with the finding that more powerful Paramount Chiefs capture civil society and enjoy more popular support (see Acemoglu et al 2014), and as a result may have been more effective at implementing and enforcing control measures. 


\section{Acknowledgements}

We thank Kate Baldwin, Erwin Bulte, Darin Christensen, Don Green, Macartan Humphreys, Leonid Peisakhin, Edward Miguel, Esther Mokuwa, Gareth Nellis, Tristan Reed, Paul

Richards, James Robinson, Beccy Wilebore, Paul Wise, the editor and three anonymous referees for helpful comments. Thanks to Han Il Chang for research assistance. Van der Windt thanks Wageningen University. Voors thanks the University of California at Berkeley. 


\section{References}

- Acemoglu, Daron, Tristan Reed, James Robinson. 2014. Chiefs: Economic Development and Elite Control of Civil Society in Sierra Leone. Journal of Political Economy 122(2): 319-68.

- Baldwin, Kate, Eric Mvukiyehe. 2015. Elections and Collective Action: Evidence from Changes in Traditional Institutions in Liberia. World Politics, 67(04), 690-725.

- Baldwin, Kate. 2016. The Paradox of Traditional Chiefs in Democratic Africa. New York City: Cambridge University Press.

- Christensen, Darin, Oeindrila Dube, Johannes Haushofer, Bilal Siddiqi, Maarten Voors. 2019. Healthcare Delivery during Crises: Experimental Evidence from Sierra Leone's Ebola Outbreak. Working paper.

- Díaz-Cayeros, Alberto, Beatriz Magaloni, Alexander Ruiz-Euler. 2014. Traditional Governance, Citizen Engagement, and Local Public Goods: Evidence from Mexico. World Development, 53, 80-93.

- Englebert, Pierre. 2000. State Legitimacy and Development. Boulder: Lynne Rienner Publishers.

- Fang, Li-Qun, Yang Yang, Jia-Fu Jiang, Hong-Wu Yao, David Kargbo, Xin-Lou Li, BaoGui Jiang, Brima Kargbo, Yi-Gang Tong, Ya-Wei Wang, Kun Liu, Abdul Kamara, Foday Dafae, Alex Kanu, Rui-Ruo Jiang, Ye Sun, Ruo-Xi Sun, Wan-Jun Chen, Mai-Juan Ma, Natalie E. Dean, Harold Thomas, Ira M. Longini, M. Elizabeth Halloran, Wu-Chun Cao. 2016. Transmission Dynamics of Ebola Virus Disease and Intervention Effectiveness in Sierra Leone. Proceedings of the National Academy of Sciences 113(16): 4488-93.

- Fanthorpe, Richard. 2005. On the Limits of Liberal Peace: Chiefs and Democratic Decentralization in Post-War Sierra Leone. African Affairs 105(418): 27-49. 
- Faye, Sylvain Landry. 2015. L'”Exceptionnalité" d'Ebola et les "Réticences" Populaires en Guinée-Conakry. Réflexions à Partir d'une Approche d'Anthropologie Symétrique, Anthropologie \& Santé 11

- Goldstein, Markus, and Christopher Udry (2008). The Profits of Power: Land Rights and Agricultural Investment in Ghana. Journal of Political Economy, 116(6), 981-1022.

- Goist, Mitchell, and Florian G. Kern. 2018. Traditional Institutions and Social Cooperation: Experimental Evidence from the Buganda Kingdom. Research and Politics, 5(1), 1-9.

- Herbst, Jeffrey. 2000. States and Power in Africa: Comparative Lessons in Authority and Control. Princeton: Princeton University Press.

- Holzinger, Katharina, Florian G. Kern and Daniela Kromrey (2016) The Dualism of Contemporary Traditional Governance and the State: Institutional Setups and Political Consequences, Political Research Quarterly, 69( 3): 469-481

- Logan, Carolyn. 2009. Selected Chiefs, Elected Councilors and Hybrid Democrats: Popular Perspectives on the Co-existence of Democracy and Traditional Authority. Journal of Modern African Studies, 47(1): 101-128.

- Logan, Carolyn. 2013. The Roots of Resilience: Exploring Popular Support for African Traditional Authorities. African Affairs, 112(448): 353-376

- Michalopoulos, Stelio, Elias Papaioannou. 2013. Pre-Colonial Ethnic Institutions and Contemporary African Development. Econometrica, 81(1), 113-152.

- Mokuwa, Esther, Maarten Voors, Erwin Bulte and Paul Richards. 2011. Peasant Grievance and Insurgency in Sierra Leone: Judicial Serfdom as a Driver of Conflict. African Affairs, 110(440): 339-366

- Moran, Mary H. 2015. Surviving Ebola: The Epidemic and Political Legitimacy in Liberia. Current History 114(772): 177-82. 
- Morse, Ben, Karen A. Grépin, Robert A. Blair, and Lily Tsai. 2016. Patterns of Demand for Non-Ebola Health Services During and After the Ebola Outbreak: Panel Survey Evidence from Monrovia, Liberia. BMJ Global Health 1(1): 1-17.

- Niang, Cheikh Ibrahima. 2014. Ebola: une Epidémie Postcoloniale, Politique Étrangère, hiver(4): 97-109.

- Nunn, Nathan, and Diego Puga. 2012. Ruggedness: The Blessing of Bad Geography in Africa, Review of Economics and Statistics, 94(1): 20-36

- Olson, Mancur. 2000. Power and Prosperity. New York: Oxford University Press.

- Osafo-Kwaako, Philip, James A. Robinson. 2013. Political Centralization in Pre-colonial Africa. Journal of Comparative Economics, 41(1), 6-21.

- Richards, Paul. 2016. Ebola: How a People's Science Helped End an Epidemic. London: Zed Books.

- WHO. 2016. Ebola Situation Report. 30 March 2016, retrieved 20 June 2019 from http://apps.who.int/ebola/current-situation/ebola-situation-report-30-march-2016 
Appendix for:

Traditional Leaders and the 2014-2015 Ebola Epidemic

25 June 2019

Content:

- Appendix A: Variable Definitions

- Appendix B: Ebola Incidence and Traditional Authority

- Appendix C: Main Results Controlling for Ruggedness

- Appendix D: Main Results Per Capita Ebola Incidence

- Appendix E: Reporting of Ebola Cases

- Appendix F: Byelaws for the Prevention of Ebola and Other Diseases 


\section{Appendix A: Variable Definitions}

Table A1 gives variable definitions of all variables in the order how they appear in the manuscript.

\section{Table A1. Variable Definitions}

\begin{tabular}{|c|c|c|}
\hline Variable & Description & Source \\
\hline $\begin{array}{l}\text { Ebola confirmed } \\
\text { cases }\end{array}$ & $\begin{array}{l}\text { Continuous, log sine transformed. Number of } \\
\text { confirmed Ebola cases in a chiefdom. Results from } \\
\text { all laboratory outcomes of "persons under } \\
\text { investigation" reported to the Sierra Leone Ministry } \\
\text { of Health and Sanitation between May } 2014 \text { and } \\
\text { September } 2015 \text {. }\end{array}$ & Fang et al (2016) \\
\hline $\begin{array}{l}\text { Number of ruling } \\
\text { families }\end{array}$ & $\begin{array}{l}\text { Continuous. Number of ruling houses per } \\
\text { chiefdom. }\end{array}$ & $\begin{array}{l}\text { Acemoglu, Reed } \\
\text { and Robinson } \\
(2014)\end{array}$ \\
\hline $\begin{array}{l}\text { Paramount Chief } \\
\text { power }\end{array}$ & $\begin{array}{l}\text { Continuous. The inverse of the number of ruling } \\
\text { families. }\end{array}$ & $\begin{array}{l}\text { Acemoglu, Reed } \\
\text { and Robinson } \\
(2014)\end{array}$ \\
\hline Chiefs recalled & $\begin{array}{l}\text { Continuous. Number of chiefs the "encyclopaedias" } \\
\text { could recall. Some chiefdoms are able to trace their } \\
\text { histories back until the eighteenth century, while } \\
\text { others can remember only back to the 1930s. }\end{array}$ & $\begin{array}{l}\text { Acemoglu, Reed } \\
\text { and Robinson } \\
(2014)\end{array}$ \\
\hline Amalgamation & $\begin{array}{l}\text { Binary. Chiefdom was amalgamated. } \\
\text { Amalgamation chiefdoms were created in the late } \\
1940 \text { s and 1950s by the colonial administration by } \\
\text { amalgamating smaller chiefdoms for tax collection } \\
\text { purposes; researchers were unable to trace lineages } \\
\text { of all the component chiefdoms. Hence the record } \\
\text { for these chiefdoms goes back only until the period } \\
\text { of amalgamation. }\end{array}$ & $\begin{array}{l}\text { Acemoglu, Reed } \\
\text { and Robinson } \\
(2014)\end{array}$ \\
\hline $\begin{array}{l}\text { Ebola incidence in } \\
\text { neighboring } \\
\text { chiefdoms }\end{array}$ & $\begin{array}{l}\text { Continuous. Sum of all Ebola cases in neighboring } \\
\text { chiefdoms. }\end{array}$ & Fang et al (2016) \\
\hline Mining permits & $\begin{array}{l}\text { Binary. Dummy for the presence of mining permits } \\
\text { in } 1930 .\end{array}$ & $\begin{array}{l}\text { Acemoglu et al } \\
(2014)\end{array}$ \\
\hline Distance to coast & $\begin{array}{l}\text { Continuous. Distance (kilometres) from the } \\
\text { chiefdom's centroid to the coast. }\end{array}$ & $\begin{array}{l}\text { Acemoglu, Reed } \\
\text { and Robinson } \\
(2014)\end{array}$ \\
\hline $\begin{array}{l}\text { Distance to nearest } \\
\text { river }\end{array}$ & $\begin{array}{l}\text { Continuous. Distance (kilometres) from the } \\
\text { chiefdom's centroid to the nearest river. }\end{array}$ & $\begin{array}{l}\text { Acemoglu, Reed } \\
\text { and Robinson } \\
(2014)\end{array}$ \\
\hline $\begin{array}{l}\text { Distance to } 1895 \\
\text { trade routes }\end{array}$ & $\begin{array}{l}\text { Continuous. Distance (kilometres) from the } \\
\text { chiefdom's centroid to } 1895 \text { trade routes as } \\
\text { reported in Mitchell (1962). }\end{array}$ & $\begin{array}{l}\text { Acemoglu, Reed } \\
\text { and Robinson } \\
(2014)\end{array}$ \\
\hline
\end{tabular}




\begin{tabular}{|c|c|c|}
\hline $\begin{array}{l}\text { Distance to } 1907 \\
\text { railroad }\end{array}$ & $\begin{array}{l}\text { Continuous. Distance (kilometres) from the } \\
\text { chiefdom's centroid to the } 1907 \text { railroad. }\end{array}$ & $\begin{array}{l}\text { Acemoglu, Reed } \\
\text { and Robinson } \\
(2014)\end{array}$ \\
\hline $\begin{array}{l}\text { Minimum distance } \\
\text { to major city }\end{array}$ & $\begin{array}{l}\text { Continuous. Minimum distance (kilometres) to } \\
\text { Sierra Leone's three major towns: Bo, Kenema and } \\
\text { Freetown. }\end{array}$ & $\begin{array}{l}\text { Acemoglu, Reed } \\
\text { and Robinson } \\
(2014)\end{array}$ \\
\hline Population & Continuous. Chiefdom's population size in 2004. & $\begin{array}{l}\text { Acemoglu, Reed } \\
\text { and Robinson } \\
(2014)\end{array}$ \\
\hline Ruggedness index & $\begin{array}{l}\text { Continuous. Index indicating the variability in } \\
\text { elevation over a } 3 \times 3 \mathrm{~km} \text { square. }\end{array}$ & $\begin{array}{l}\text { Own calculations } \\
\text { from USGS } \\
(2006)\end{array}$ \\
\hline Process time & $\begin{array}{l}\text { Continuous (in days). Average time between onset } \\
\text { of symptom and sample test. Average across } \\
\text { confirmed and suspected cases. }\end{array}$ & Fang et al (2016) \\
\hline Presence facility & $\begin{array}{l}\text { Continuous ( } 0 \text { to } 1) \text {. Is there a clinic or hospital in } \\
\text { this village / town / city? Averaged by chiefdom. }\end{array}$ & NPS 2007: K29 \\
\hline Presence doctor & $\begin{array}{l}\text { Continuous ( } 0 \text { to } 1) \text {. Is there a nurse / } \mathrm{CHO} / \text { doctor } \\
\text { currently posted to this clinic / hospital? Averaged } \\
\text { by chiefdom. }\end{array}$ & NPS 2007: K39 \\
\hline Presence nurse & $\begin{array}{l}\text { Continuous ( } 0 \text { to } 1) \text {. Is there a trained nurse that } \\
\text { lives in this community? Averaged by chiefdom. }\end{array}$ & NPS 2007: K31 \\
\hline Cost to use & $\begin{array}{l}\text { Continuous ( } 0 \text { to } 1) \text {. If you only have a little } \\
\text { money, can you still get treatment at the clinic / } \\
\text { hospital? Averaged by chiefdom. }\end{array}$ & NPS 2007: K40 \\
\hline $\begin{array}{l}\text { Use government } \\
\text { health facility }\end{array}$ & $\begin{array}{l}\text { Continuous ( } 0 \text { to } 1) \text {. In the past month, have you or } \\
\text { anyone in your household sought treatment from a } \\
\text { government clinic (CHC, CHP, MCHP)? Averaged } \\
\text { by chiefdom. }\end{array}$ & NPS 2007: H1a \\
\hline $\begin{array}{l}\text { Use traditional } \\
\text { health facility }\end{array}$ & $\begin{array}{l}\text { Continuous ( } 0 \text { to } 1) \text {. In the past month, have you or } \\
\text { anyone in your household sought treatment from a } \\
\text { traditional healer? Averaged by chiefdom. }\end{array}$ & NPS 2007: H1b \\
\hline Use pharmacy & $\begin{array}{l}\text { Continuous ( } 0 \text { to } 1) \text {. In the past month, have you or } \\
\text { anyone in your household visited a pharmacist? } \\
\text { Averaged by chiefdom. }\end{array}$ & NPS 2007: H1c \\
\hline $\begin{array}{l}\text { Ebola suspected } \\
\text { cases }\end{array}$ & $\begin{array}{l}\text { Continuous, log sine transformed. Number of } \\
\text { suspected Ebola cases in a chiefdom. Results from } \\
\text { all laboratory outcomes of "persons under } \\
\text { investigation" reported to the Sierra Leone Ministry } \\
\text { of Health and Sanitation between May } 2014 \text { and } \\
\text { September } 2015 \text {. }\end{array}$ & Fang et al (2016) \\
\hline
\end{tabular}




\section{Appendix B: Ebola Incidence and Traditional Authority}

Figure B1. Ebola Incidence and Traditional Authority

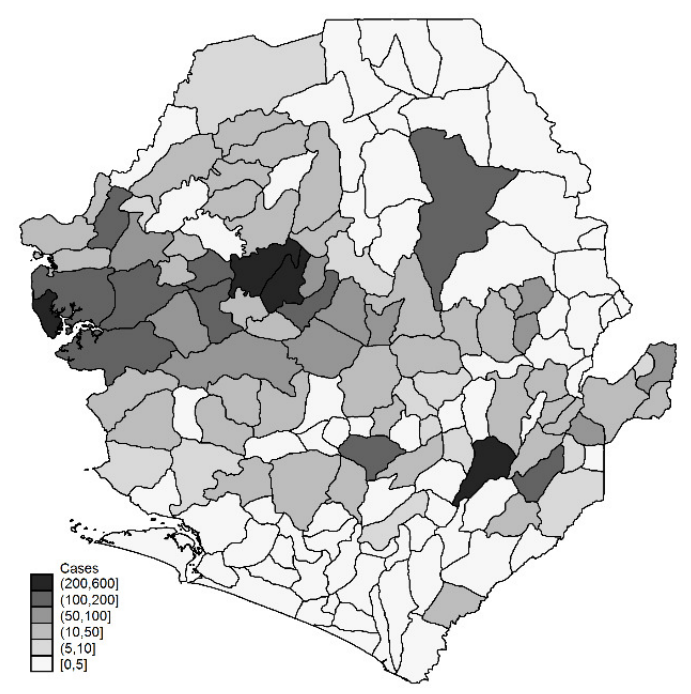

(a) Ebola Incidence

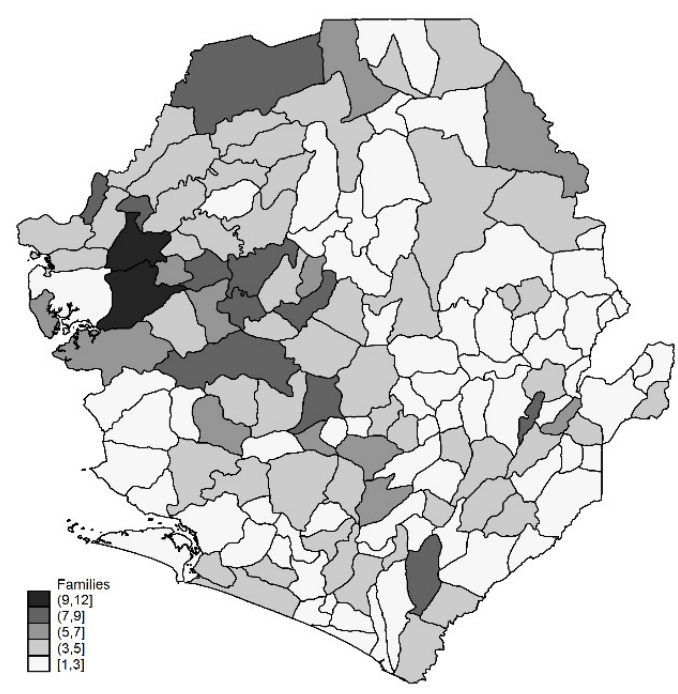

(b) Traditional Authority

Notes: Authors' drawing. Ebola data from Fang et al (2016). Traditional authority data from Acemoglu, Reed and Robinson (2014). 


\section{Appendix C: Main Results Controlling for Ruggedness}

Table $\mathbf{C 1}$ replicates the results table in the main text (Table 2) adding a control for differenced terrain heterogeneity using a ruggedness index, similarly to Nunn and Puga (2012), see also Riley et al (1999). To create a $\sim 1 \mathrm{~km}$ resolution ruggedness measure for Sierra Leone we use a 30arc second (1km) Digital Elevation Model from NASA SRTM, mosaicked and re-projected to WGS 84/UTM zone 29N in QGIS v3.4.3. Ruggedness was calculated on 3x3 pixel grid, using the Raster Terrain Analysis plugin in QGIS. The responding ruggedness index reflects how variable the elevation is over a $3 \times 3 \mathrm{~km}$ square. Data are from USGS (2006). See Nunn and Puga (2012) for a more detailed exposition.

Table C1. Paramount Chief Power and Ebola Cases, Terrain Control

\begin{tabular}{|c|c|c|c|c|c|c|}
\hline & $\begin{array}{c}(1) \\
\text { Basic }\end{array}$ & $\begin{array}{c}(2) \\
\text { FEs + } \\
\text { Controls }\end{array}$ & $\begin{array}{c}\text { (3) } \\
\text { Neg. Bin. }\end{array}$ & $\begin{array}{c}\text { (4) } \\
\text { Population }\end{array}$ & $\begin{array}{c}\text { (5) } \\
\text { Spatial }\end{array}$ & $\begin{array}{c}\text { (6) } \\
\text { Exposure }\end{array}$ \\
\hline Paramount Chief power & $\begin{array}{c}-0.289 * * * \\
(0.08\end{array}$ & $\begin{array}{c}-0.155^{* *} \\
(0.077)\end{array}$ & $\begin{array}{l}-0.181^{* *} \\
(0.081)\end{array}$ & $\begin{array}{c}-0.141^{* *} \\
(0.066)\end{array}$ & $\begin{array}{l}-0.141^{* *} \\
(0.066)\end{array}$ & $\begin{array}{c}-0.167 * * \\
(0.068)\end{array}$ \\
\hline Chiefs recalled & & $\begin{array}{c}0.049 \\
(0.082)\end{array}$ & $\begin{array}{l}0.026 \\
(0.07)\end{array}$ & $\begin{array}{l}-0.026 \\
(0.071)\end{array}$ & $\begin{array}{l}-0.025 \\
(0.071)\end{array}$ & $\begin{array}{c}0.005 \\
(0.076)\end{array}$ \\
\hline Amalgamation & & $\begin{array}{c}0.004 \\
(0.092)\end{array}$ & $\begin{array}{l}-0.022 \\
(0.081)\end{array}$ & $\begin{array}{l}-0.032 \\
(0.079)\end{array}$ & $\begin{array}{l}-0.036 \\
(0.082)\end{array}$ & $\begin{array}{l}-0.004 \\
(0.088)\end{array}$ \\
\hline Mining & & $\begin{array}{l}0.162 * * \\
(0.073)\end{array}$ & $\begin{array}{l}0.122 * * \\
(0.059)\end{array}$ & $\begin{array}{c}0.087 \\
(0.064)\end{array}$ & $\begin{array}{c}0.085 \\
(0.065)\end{array}$ & $\begin{array}{c}0.079 \\
(0.063)\end{array}$ \\
\hline Coast & & $\begin{array}{c}0.075 \\
(0.193)\end{array}$ & $\begin{array}{c}0.144 \\
(0.176)\end{array}$ & $\begin{array}{c}0.188 \\
(0.166)\end{array}$ & $\begin{array}{l}0.181 \\
(0.17)\end{array}$ & $\begin{array}{l}0.435 * * \\
(0.187)\end{array}$ \\
\hline Nearest river & & $\begin{array}{c}0.067 \\
(0.069)\end{array}$ & $\begin{array}{c}0.055 \\
(0.066)\end{array}$ & $\begin{array}{l}0.031 \\
(0.06)\end{array}$ & $\begin{array}{c}0.03 \\
(0.06)\end{array}$ & $\begin{array}{l}-0.005 \\
(0.065)\end{array}$ \\
\hline Trade route & & $\begin{array}{l}-0.089 \\
(0.107)\end{array}$ & $\begin{array}{l}-0.065 \\
(0.094)\end{array}$ & $\begin{array}{l}-0.129 \\
(0.092)\end{array}$ & $\begin{array}{l}-0.124 \\
(0.095)\end{array}$ & $\begin{array}{l}-0.123 \\
(0.095)\end{array}$ \\
\hline Railroad & & $\begin{array}{l}-0.284 * \\
(0.158)\end{array}$ & $\begin{array}{c}-0.251^{*} \\
(0.13)\end{array}$ & $\begin{array}{c}-0.291 * * \\
(0.135)\end{array}$ & $\begin{array}{l}-0.281 * \\
(0.144)\end{array}$ & $\begin{array}{l}-0.224 \\
(0.152)\end{array}$ \\
\hline Major city & & $\begin{array}{l}-0.247 \\
(0.189)\end{array}$ & $\begin{array}{l}-0.209 \\
(0.158)\end{array}$ & $\begin{array}{l}-0.074 \\
(0.164)\end{array}$ & $\begin{array}{l}-0.073 \\
(0.165)\end{array}$ & $\begin{array}{l}-0.203 \\
(0.186)\end{array}$ \\
\hline Population size & & & & $\begin{array}{c}0.437 * * * \\
(0.064)\end{array}$ & $\begin{array}{c}0.433 * * * \\
(0.067)\end{array}$ & $\begin{array}{c}0.346 * * * \\
(0.064)\end{array}$ \\
\hline Ebola neighbors & & & & & $\begin{array}{c}0.019 \\
(0.095)\end{array}$ & $\begin{array}{c}0.023 \\
(0.093)\end{array}$ \\
\hline Ruggedness Index & $\begin{array}{c}-0.002 \\
(0.002)\end{array}$ & $\begin{array}{l}-0.005^{*} \\
(0.003)\end{array}$ & $\begin{array}{c}-0.003 \\
(0.002)\end{array}$ & $\begin{array}{l}-0.003 \\
(0.002)\end{array}$ & $\begin{array}{l}-0.003 \\
(0.002)\end{array}$ & $\begin{array}{l}-0.003 \\
(0.002)\end{array}$ \\
\hline $\begin{array}{l}\text { District FEs } \\
\text { Regression }\end{array}$ & $\begin{array}{c}\mathrm{N} \\
\mathrm{OLS}\end{array}$ & $\begin{array}{c}\mathrm{Y} \\
\text { OLS }\end{array}$ & $\begin{array}{c}\text { Y } \\
\text { Neg. Bin. }\end{array}$ & $\begin{array}{c}\mathrm{Y} \\
\text { OLS }\end{array}$ & $\begin{array}{c}\mathrm{Y} \\
\text { OLS }\end{array}$ & $\begin{array}{c}\mathrm{Y} \\
\mathrm{OLS}\end{array}$ \\
\hline
\end{tabular}




$\begin{array}{ccccccc}\mathrm{N} & 149 & 149 & 149 & 149 & 149 & 112 \\ \mathrm{R}^{2} & 0.100 & 0.533 & \mathrm{NA} & 0.659 & 0.659 & 0.616\end{array}$

Note: Regressions at chiefdom level. All variables are standardized. Standard errors in parentheses. $* \mathrm{p}<0.10, * * \mathrm{p}<0.05, * * * \mathrm{p}<0.01$ (two-tailed). 


\section{Appendix D: Main Results Per Capita Ebola Incidence}

Table D1 replicates the results table in the main text (Table 2) but the dependent variable is rescaled by the chiefdom's population size.

Table D1. Paramount Chief Power and Per Capita Ebola Cases

\begin{tabular}{|c|c|c|c|c|}
\hline & $\begin{array}{c}(1) \\
\text { Basic }\end{array}$ & $\begin{array}{c}\text { (2) } \\
\text { FEs + } \\
\text { Controls }\end{array}$ & $\begin{array}{c}(3) \\
\text { Spatial }\end{array}$ & $\begin{array}{c}(4) \\
\text { Exposure }\end{array}$ \\
\hline Paramount Chief power & $\begin{array}{c}-0.263^{* * *} \\
(0.080)\end{array}$ & $\begin{array}{l}-0.172^{* *} \\
(0.079)\end{array}$ & $\begin{array}{l}-0.171^{* *} \\
(0.079)\end{array}$ & $\begin{array}{c}-0.190^{* *} \\
(0.081)\end{array}$ \\
\hline Chiefs recalled & & $\begin{array}{c}0.008 \\
(0.085)\end{array}$ & $\begin{array}{c}0.006 \\
(0.085)\end{array}$ & $\begin{array}{c}0.034 \\
(0.089)\end{array}$ \\
\hline Amalgamation & & $\begin{array}{l}-0.020 \\
(0.095)\end{array}$ & $\begin{array}{l}-0.040 \\
(0.098)\end{array}$ & $\begin{array}{l}-0.009 \\
(0.105)\end{array}$ \\
\hline Mining & & $\begin{array}{c}0.070 \\
(0.073)\end{array}$ & $\begin{array}{c}0.062 \\
(0.074)\end{array}$ & $\begin{array}{c}0.054 \\
(0.072)\end{array}$ \\
\hline Coast & & $\begin{array}{c}0.041 \\
(0.194)\end{array}$ & $\begin{array}{c}0.020 \\
(0.196)\end{array}$ & $\begin{array}{c}0.376^{*} \\
(0.211)\end{array}$ \\
\hline Nearest river & & $\begin{array}{c}0.051 \\
(0.072)\end{array}$ & $\begin{array}{c}0.047 \\
(0.072)\end{array}$ & $\begin{array}{c}0.005 \\
(0.078)\end{array}$ \\
\hline Trade route & & $\begin{array}{l}-0.109 \\
(0.109)\end{array}$ & $\begin{array}{l}-0.084 \\
(0.113)\end{array}$ & $\begin{array}{l}-0.089 \\
(0.112)\end{array}$ \\
\hline Railroad & & $\begin{array}{l}-0.299^{*} \\
(0.163)\end{array}$ & $\begin{array}{l}-0.251 \\
(0.171)\end{array}$ & $\begin{array}{l}-0.225 \\
(0.180)\end{array}$ \\
\hline Major city & & $\begin{array}{l}-0.221 \\
(0.195)\end{array}$ & $\begin{array}{l}-0.207 \\
(0.196)\end{array}$ & $\begin{array}{l}-0.355 \\
(0.221)\end{array}$ \\
\hline Ebola neighbors & & & $\begin{array}{c}0.097 \\
(0.108)\end{array}$ & $\begin{array}{c}0.082 \\
(0.105)\end{array}$ \\
\hline District FEs & $\mathrm{N}$ & $\mathrm{Y}$ & $\mathrm{Y}$ & $\mathrm{Y}$ \\
\hline Regression & OLS & OLS & OLS & OLS \\
\hline $\mathrm{N}$ & 149 & 149 & 149 & 112 \\
\hline $\mathrm{R}^{2}$ & 0.069 & 0.496 & 0.499 & 0.439 \\
\hline
\end{tabular}

Note: Regressions at chiefdom level. Standard errors in parentheses. ${ }^{*} \mathrm{p}<0.10,{ }^{* *} \mathrm{p}<0.05$, $* * * \mathrm{p}<0.01$ (two-tailed). 


\section{Appendix E: Reporting of Ebola Cases}

This study finds that Chiefdoms with more powerful traditional leaders saw substantially fewer laboratory-confirmed Ebola cases of "persons under investigation". This study argues that this result obtains because of the activities undertaken by Paramount Chiefs to combat the disease. An alternative explanation, however, is simply that in Chiefdoms with stronger traditional leaders fewer Ebola cases were reported. In this section, we provide evidence that this is not the case. We explore the three factors via which such underreporting may have taken place: 1) the absence of Ebola response infrastructure via which reporting took place, 2) the inability and unwillingness of citizens to report Ebola cases, and 3) the low quality of diagnosis tests of suspected Ebola cases. We show that these factors are unrelated to the power of the Paramount Chief.

\section{Ebola response infrastructure}

"Persons under investigation" had their blood or nasopharyngeal swab samples collected and sent to government-appointed laboratories. Underreporting may thus occur in Chiefdoms with more powerful Paramount Chiefs if these Chiefdoms had less Ebola response infrastructure to report to, and to collect and diagnose samples. Three bits of evidence suggest this unlikely to be the case.

First, to collect, transport and diagnose samples, the government of Sierra Leone worked together with international partners such as the World Health Organization, the Centers for Disease Control and Prevention, NGOs and other countries such as the United Kingdom. ${ }^{6}$

\footnotetext{
${ }^{6}$ A careful discussion about the response to the Ebola crisis is beyond the scope of this paper. The World Health Organization has more information: http://www.who.int/csr/disease/ebola/en/.
} 
These actors targeted their Ebola response locations based on the incidence of Ebola, not the characteristics of the Paramount Chiefs.

Second, more powerful Paramount Chiefs may govern more isolated Chiefdoms; i.e. Chiefdoms that may be difficult to reach by Ebola response actors. Columns (2) to (6) in Table 2, however, control for such isolation, using the Chiefdom's centroid distance from the coast and the country's three major cities: Bo, Kenema and Freetown. As an additional test, we can make use of the data collected by Fang et al (2016). For each Ebola case, the data include the date of symptom onset and sample tested. Variation in the difference between these dates, or "process time", is due in large part to the time it takes to collect and transport a sample. We thus calculate the average process time by Chiefdom and take that as an indicator for the isolation of a Chiefdom. Table E2 presents the results (see Table E1 for descriptive statistics), where we repeat the main empirical model of Table 2's Column (2), where we replace the dependent variable with process time. We find no evidence that the strength of the Paramount Chief is related to a Chiefdom's isolation of Ebola reporting. Finally, in Table C1 we showed that adding a control for ruggedness, a possible indicator for a chiefdom's level of isolation, produces similar results as reported in the main text. ${ }^{7}$

Third, Ebola response infrastructure may gravitate towards areas that have already health infrastructure present. The worry thus would be that Chiefdoms with more powerful Paramount Chiefs have fewer health facilities at the onset of the Ebola outbreak. To test this claim, we make use of the National Public Services (NPS) survey, a nationally representative survey conducted in 2007 (NPS, 2007). ${ }^{8}$ Table E2 presents the results, where we again repeat

\footnotetext{
${ }^{7}$ Our measure for ruggedness is positively correlated with the other measures of isolation and has a very similar relationship to chiefly power. That is, when we run a regression akin to the "balance test" in Table 3 in Acemoglu, Reed and Robinson (2014), we find that ruggedness and chiefly power are unrelated $(\mathrm{p}$-value $=0.25)$ and similar in size to the other geographic controls (e.g. distance to major towns).

${ }^{8}$ NPS did not collect data in Gbo and Yawbeko chiefdoms.
} 
the main empirical model of Table 2's Column (2), but replace the dependent variable. Columns (2) to (4) show that the power of the Paramount Chief is unrelated to the presence of a clinic or a hospital, the presence of a doctor, and the presence of a nurse in these facilities at the onset of the Ebola crisis.

\section{Individuals' ability and willingness to report}

The presence of the Ebola response infrastructure may be unrelated to the power of the Paramount Chief. However, one may be worried that individuals in Chiefdoms with more powerful traditional leaders are less able or willing to report Ebola cases to these infrastructures in the first place. This concern is particularly relevant given the results in Acemoglu et al (2014) and the observation that Paramount Chiefs enjoy more trust than the government, and thus also likely more trust than the formal Ebola response, in rural Sierra Leone (Richards et al 2015). Two bits of evidence suggest that this is not a concern.

First, we return to the NPS survey, which also collected information about individuals' costs to use health facilities, and their use of health facilities, specifically government clinics, traditional healers, and pharmacists. Columns (5) to (8) in Table E2 show that at the onset of the Ebola epidemic the ability and willingness to use (government-provided) health facilities was unrelated to the power of the Paramount Chief.

Second, the Fang et al (2016) data also include information about the number of suspected Ebola cases. We combine this information with this study's outcome - the number of laboratory-confirmed cases - to calculate the total number of Ebola cases reported per Chiefdom. Column (9) in Table E2 shows that the power of the Paramount Chief does not influence the total number of Ebola cases reported across Chiefdoms. In fact, combined with this study's main result, this observation is consistent with a story in which Chiefdoms with more powerful Paramount Chiefs experience fewer Ebola-infected people, but where, 
conditional on the number of people infected with Ebola, vigilance and reporting was in fact relatively higher.

\section{Quality of laboratory diagnoses}

A final worry may be that that the quality of Ebola virus laboratory testing was worse in Chiefdoms with more powerful traditional leaders, thereby leading to fewer laboratoryconfirmed Ebola cases. This claim is not likely to hold because laboratory diagnoses were mainly conducted by international actors such as the WHO and CDC. Furthermore, laboratories operated under internal guidelines related to the collection of blood samples, the safe shipment of samples, and the laboratory diagnosis of samples. One may argue, however, that it took time before international support was in place and all Ebola diagnoses tests were undertaken using high standards. To test this claim we re-estimate Column (2) in Table 2 but we do not take into account the first three months for which we have data. The first laboratory-confirmed case in our dataset is 18 May 2014. At that time, the international response was already taking shape. In June, for example, MSF opened an Ebola treatment centre in Kailahun, and the WHO helped establish a mobile laboratory. In July, the CDC activated its Emergency Operations Center in Sierra Leone. Column (10) in Table E2 shows that we obtain similar results. ${ }^{9}$

\footnotetext{
${ }^{9}$ In fact, we get the same result if we delete the first to sixth month.
} 
Table E1. Additional Descriptive Statistics

\begin{tabular}{llccccc}
\hline$\#$ & Label & N & Mean & SD & Min & Max \\
\hline 1 & Presence facility & 147 & 0.26 & 0.32 & 0 & 1 \\
2 & Presence doctor & 141 & 0.98 & 0.08 & 0.5 & 1 \\
3 & Presence nurse & 132 & 0.05 & 0.16 & 0 & 1 \\
4 & Time between symptom and test & 107 & 6.3 & 1.85 & 3.17 & 15.67 \\
\hline 5 & Cost of use & 141 & 0.67 & 0.36 & 0 & 1 \\
6 & Use government health facility & 147 & 0.66 & 0.2 & 0.1 & 1 \\
7 & Use traditional health facility & 147 & 0.16 & 0.16 & 0 & 0.56 \\
8 & Use pharmacist & 147 & 0.07 & 0.11 & 0 & 0.5 \\
9 & Ebola suspected cases & 149 & 15.29 & 24.73 & 0 & 152 \\
\hline 10 & Ebola confirmed cases (>3 months) & 149 & 29.24 & 65.48 & 0 & 581 \\
\hline
\end{tabular}

Notes: For detailed variable descriptions, see Table A1. 
Table E2. Paramount Chief Power and Reporting of Ebola Cases

\begin{tabular}{|c|c|c|c|c|c|c|c|c|c|c|}
\hline & $\begin{array}{c}(1) \\
\text { Process } \\
\text { time }\end{array}$ & $\begin{array}{c}(2) \\
\text { Presence } \\
\text { facility }\end{array}$ & $\begin{array}{c}(3) \\
\text { Presence } \\
\text { doctor }\end{array}$ & $\begin{array}{c}(4) \\
\text { Presence } \\
\text { nurse }\end{array}$ & $\begin{array}{c}(5) \\
\text { Cost to } \\
\text { use }\end{array}$ & $\begin{array}{l}\text { (6) } \\
\text { Use } \\
\text { gov. }\end{array}$ & $\begin{array}{c}(7) \\
\text { Use } \\
\text { trad. }\end{array}$ & $\begin{array}{c}\text { (8) } \\
\text { Use } \\
\text { pharmacy }\end{array}$ & $\begin{array}{l}(9) \\
\text { Total }\end{array}$ & $\begin{array}{c}(10) \\
\text { Month } \\
>3\end{array}$ \\
\hline $\begin{array}{l}\text { Paramount } \\
\text { Chief power }\end{array}$ & $\begin{array}{l}-0.058 \\
(0.125) \\
\end{array}$ & $\begin{array}{c}0.125 \\
(0.102) \\
\end{array}$ & $\begin{array}{c}0.083 \\
(0.108) \\
\end{array}$ & $\begin{array}{c}-0.06 \\
(0.112) \\
\end{array}$ & $\begin{array}{c}0.029 \\
(0.096) \\
\end{array}$ & $\begin{array}{c}0.127 \\
(0.092) \\
\end{array}$ & $\begin{array}{c}0.013 \\
(0.076) \\
\end{array}$ & $\begin{array}{l}-0.071 \\
(0.073) \\
\end{array}$ & $\begin{array}{l}-0.103 \\
(0.081)\end{array}$ & $\begin{array}{c}-0.165 * * \\
(0.079)\end{array}$ \\
\hline Chiefs recalled & $\begin{array}{l}-0.029 \\
(0.129)\end{array}$ & $\begin{array}{l}0.145 \\
(0.11)\end{array}$ & $\begin{array}{l}-0.008 \\
(0.117)\end{array}$ & $\begin{array}{l}0.228 * * \\
(0.113)\end{array}$ & $\begin{array}{l}-0.113 \\
(0.104)\end{array}$ & $\begin{array}{c}-0.091 \\
(0.099)\end{array}$ & $\begin{array}{c}0.034 \\
(0.082)\end{array}$ & $\begin{array}{c}0.081 \\
(0.079)\end{array}$ & $\begin{array}{c}0.1 \\
(0.087)\end{array}$ & $\begin{array}{c}0.054 \\
(0.084)\end{array}$ \\
\hline Amalgamation & $\begin{array}{l}-0.184 \\
(0.149)\end{array}$ & $\begin{array}{c}-0.03 \\
(0.125)\end{array}$ & $\begin{array}{l}-0.086 \\
(0.132)\end{array}$ & $\begin{array}{l}0.323 * * \\
(0.125)\end{array}$ & $\begin{array}{l}-0.026 \\
(0.117)\end{array}$ & $\begin{array}{l}-0.002 \\
(0.112)\end{array}$ & $\begin{array}{c}0.135 \\
(0.092)\end{array}$ & $\begin{array}{c}0.065 \\
(0.089)\end{array}$ & $\begin{array}{c}0.105 \\
(0.098)\end{array}$ & $\begin{array}{l}-0.007 \\
(0.095)\end{array}$ \\
\hline Mining & $\begin{array}{l}-0.068 \\
(0.106)\end{array}$ & $\begin{array}{c}-0.001 \\
(0.095)\end{array}$ & $\begin{array}{c}0.035 \\
(0.103)\end{array}$ & $\begin{array}{c}-0.1 \\
(0.097)\end{array}$ & $\begin{array}{c}0.031 \\
(0.091)\end{array}$ & $\begin{array}{c}0.037 \\
(0.086)\end{array}$ & $\begin{array}{c}0.074 \\
(0.071)\end{array}$ & $\begin{array}{l}0.187 * * * \\
(0.068)\end{array}$ & $\begin{array}{c}0.105 \\
(0.075)\end{array}$ & $\begin{array}{c}0.097 \\
(0.073)\end{array}$ \\
\hline Coast & $\begin{array}{l}-0.111 \\
(0.308)\end{array}$ & $\begin{array}{l}-0.165 \\
(0.253)\end{array}$ & $\begin{array}{l}-0.183 \\
(0.265)\end{array}$ & $\begin{array}{l}-0.037 \\
(0.264)\end{array}$ & $\begin{array}{l}-0.400 * \\
(0.235)\end{array}$ & $\begin{array}{c}0.133 \\
(0.228)\end{array}$ & $\begin{array}{c}-0.039 \\
(0.188)\end{array}$ & $\begin{array}{c}0.162 \\
(0.181)\end{array}$ & $\begin{array}{c}0.08 \\
(0.199)\end{array}$ & $\begin{array}{c}-0.011 \\
(0.194)\end{array}$ \\
\hline Nearest river & $\begin{array}{l}-0.068 \\
(0.115)\end{array}$ & $\begin{array}{l}-0.117 \\
(0.095)\end{array}$ & $\begin{array}{l}-0.016 \\
(0.104)\end{array}$ & $\begin{array}{l}-0.015 \\
(0.11)\end{array}$ & $\begin{array}{c}0.043 \\
(0.092)\end{array}$ & $\begin{array}{c}0.077 \\
(0.086)\end{array}$ & $\begin{array}{c}0.085 \\
(0.071)\end{array}$ & $\begin{array}{l}-0.025 \\
(0.068)\end{array}$ & $\begin{array}{c}0.096 \\
(0.074)\end{array}$ & $\begin{array}{c}0.064 \\
(0.072)\end{array}$ \\
\hline Trade route & $\begin{array}{c}-0.158 \\
(0.176)\end{array}$ & $\begin{array}{c}-0.017 \\
(0.142)\end{array}$ & $\begin{array}{c}0.081 \\
(0.159)\end{array}$ & $\begin{array}{l}0.174 \\
(0.15)\end{array}$ & $\begin{array}{c}-0.06 \\
(0.141)\end{array}$ & $\begin{array}{c}-0.073 \\
(0.128)\end{array}$ & $\begin{array}{l}-0.108 \\
(0.106)\end{array}$ & $\begin{array}{l}-0.181 * \\
(0.102)\end{array}$ & $\begin{array}{l}-0.129 \\
(0.112)\end{array}$ & $\begin{array}{l}-0.099 \\
(0.109)\end{array}$ \\
\hline Railroad & $\begin{array}{c}0.077 \\
(0.255)\end{array}$ & $\begin{array}{c}0.112 \\
(0.212)\end{array}$ & $\begin{array}{c}0.192 \\
(0.224)\end{array}$ & $\begin{array}{c}0.017 \\
(0.217)\end{array}$ & $\begin{array}{l}-0.121 \\
(0.199)\end{array}$ & $\begin{array}{c}0.073 \\
(0.191)\end{array}$ & $\begin{array}{c}0.527 * * * \\
(0.157)\end{array}$ & $\begin{array}{c}0.261 * \\
(0.152)\end{array}$ & $\begin{array}{c}-0.392 * * \\
(0.167)\end{array}$ & $\begin{array}{l}-0.269 \\
(0.163)\end{array}$ \\
\hline Major city & $\begin{array}{c}-0.004 \\
(0.325)\end{array}$ & $\begin{array}{c}-0.121 \\
(0.253)\end{array}$ & $\begin{array}{l}-0.121 \\
(0.268)\end{array}$ & $\begin{array}{c}-0.19 \\
(0.258)\end{array}$ & $\begin{array}{c}0.233 \\
(0.238)\end{array}$ & $\begin{array}{c}0.022 \\
(0.229)\end{array}$ & $\begin{array}{l}-0.204 \\
(0.188)\end{array}$ & $\begin{array}{l}-0.181 \\
(0.182)\end{array}$ & $\begin{array}{c}-0.281 \\
(0.2)\end{array}$ & $\begin{array}{l}-0.279 \\
(0.194)\end{array}$ \\
\hline District FEs & $\mathrm{Y}$ & $\mathrm{Y}$ & $\mathrm{Y}$ & $\mathrm{Y}$ & $\mathrm{Y}$ & $\mathrm{Y}$ & $\mathrm{Y}$ & $\mathrm{Y}$ & $\mathrm{Y}$ & $\mathrm{Y}$ \\
\hline $\begin{array}{l}\mathrm{N} \\
\mathrm{R}^{2}\end{array}$ & $\begin{array}{l}\text { OLS } \\
107\end{array}$ & $\begin{array}{l}\text { OLS } \\
147\end{array}$ & $\begin{array}{l}\text { OLS } \\
141\end{array}$ & $\begin{array}{l}\text { OLS } \\
132\end{array}$ & $\begin{array}{l}\text { OLS } \\
141\end{array}$ & $\begin{array}{l}\text { OLS } \\
147\end{array}$ & $\begin{array}{l}\text { OLS } \\
147\end{array}$ & $\begin{array}{l}\text { OLS } \\
147\end{array}$ & $\begin{array}{l}\text { OLS } \\
149\end{array}$ & $\begin{array}{l}\text { OLS } \\
149\end{array}$ \\
\hline
\end{tabular}

Note: Regressions at Chiefdom level. Regressions include the number of Chiefs recalled and amalgamation of Chiefdoms plus the six geographic controls. Standard errors in parentheses. $* \mathrm{p}<0.10, * * \mathrm{p}<0.05, * * * \mathrm{p}<0.01$ (two-tailed). 


\section{Appendix F: Byelaws for the Prevention of Ebola and Other Diseases}

Below we list the Byelaws for the Prevention of Ebola and Other Diseases approved by Parliament on Friday 8th August 2014 under section 29 of the Constitution of Sierra Leone Act No. 6 of 1991.

Retrieved on 25 June 2019 from:

https://www.humanitarianresponse.info/sites/www.humanitarianresponse.info/files/document s/files/by-laws.pdf

\section{BYE LAWS FOR ALL CHIEFDOMS IN SIERRA LEONE BYELAWS FOR THE PREVENTION OF EBOLA AND OTHER DISEASES}

\section{Communication of Ebola}

Section 1

No one should keep or harbour any person suspected of having contracted the Ebola virus disease.

Nobody shall conceal any person who is sick from any disease. All illness must be reported to competent health authorities promptly.

Any breach of these provisions is liable to a fine of up to Five Hundred Thousand Leones (Le. 500,000) and/or a term of Six (6) months imprisonment.

Section 2

All strangers arriving in any residential area shall be immediately reported by their host, guest house or hotel to the competent chiefdom authorities having the rank of at least a Paramount Chief, Speaker, Section Chief, Sub-Chief or Village Chief.

Any person who knowingly harbours an unregistered stranger is liable to a fine of up to Five Hundred Thousand Leones (Le. 500,000) and/or a term of Six (6) months imprisonment.

Section 3

It is an offence under this Bye-law to distort or send any misleading information on Ebola virus disease or other diseases. Any information on Ebola or other diseases must be geared towards the prevention and control of Ebola or the said disease.

Any breach of this provision is liable to a fine of up to Five Hundred Thousand Leones (Le. 500,000) and/or a term of Six (6) months imprisonment.

\section{Treatment of Ebola Patients}

Section 4

The Government Hospitals, Peripheral Health Units (PHUs) or hospitals or treatment centres approved by Government for the treatment of the Ebola virus disease and other 
contagious diseases shall be the only recognized facilities for the treatment of these diseases.

No person (including herbalists and "pepper doctors") shall offer or be involved in the treatment of a patient for the Ebola virus disease or other contagious disease at home. Any breach of this provision is liable to a fine of up to Five Hundred Thousand Leones (Le. 500,000) and/or a term of Six (6) months imprisonment, and loss of professional certificate where applicable.

Section 5

Any person who is suspected of having contracted the Ebola virus and other contagious diseases shall be quarantined and monitored for twenty one (21) days or more by the appropriate medical personnel and the security forces.

Any breach of this provision is liable to a fine of up to Five Hundred Thousand Leones (Le. 500,000) and / or a term of Six (6) months imprisonment.

Section 6

All patients successfully treated for the Ebola virus and other contagious diseases shall, on return to their home communities, report and present their Discharge Cards to the Paramount Chief. Any former patient who fails to do so shall be liable to a fine of up to One Hundred Thousand Leones (Le. 100,000).

Section 7

Patients treated and recovered from Ebola Virus and other contagious diseases shall be welcomed within their communities without any stigma.

Any person who acts in a way that intends to stigmatise a recovered patient shall be liable to a fine of up to Two Hundred Thousand Leones (Le. 200,000).

\section{Death and Burial}

Section 8

All deaths must be reported to the appropriate chiefdom authority, Paramount Chief, Section Chief, Sub-Chief or Village Chief.

It is an offence under this Byelaw for any person to be involved in the burial of the dead without the permission from the Paramount Chief, Section Chief, Sub-Chief or Village Chief.

Any breach of these provisions is liable to a fine of Five Hundred Thousand Leones (Le. $500,000)$ and / or a term of Six (6) months imprisonment.

Section 9

All washing of the dead is prohibited without a permit from the Paramount Chief, Section Chief, Sub-Chief or Village Chief in consultation with the relevant health authority. Any breach of this provision is liable to a fine of Five Hundred Thousand Leones (Le. $500,000)$ and /or a term of Six (6) months imprisonment.

Section 10

No cemetery worker or community grave digger shall allow or permit anyone to be buried without the permission of the Paramount Chief, Section Chief, Sub-Chief, Village Chief or the Local Council where applicable.

Any breach of this provision is liable to a fine of Five Hundred Thousand Leones (Le. $500,000)$ and / or a term of Six (6) months imprisonment. 


\section{Section 11}

All Funeral Rites including wakes, 3rd day, 7th day, 40th day and other ceremonies, are suspended until such time when the temporary ban has been lifted by the appropriate authority.

Any breach of this provision is liable to a fine of Five Hundred Thousand Leones (Le. $500,000)$ and / or a term of Six (6) months imprisonment.

\section{Miscellaneous Provisions}

Section 12

All secret societies and initiations are prohibited by this bye-law until such time when the temporary ban has been lifted by the appropriate authority.

All forms of circumcision for fowl (fol) is outlawed.

Any breach of these provisions is liable to a fine of Five Hundred Thousand Leones (Le. $500,000)$ and / or a term of Six (6) months imprisonment for both the initiator and parent/guardian of the child.

Section 13

All hunting or sale of any bush meat in the chiefdom or locality is prohibited until such time when the temporary ban has been lifted by the appropriate authority.

Any breach of this provision is liable to a fine of Two Hundred Thousand Leones (Le. 200,000) and confiscation of the said meat by the Paramount Chief/Sub-Chiefs/Section Chiefs /Village Chiefs who must destroy the meat immediately.

Section 14

All Lumas/Doweis and public gatherings are prohibited until such time when the temporary ban has been lifted by the appropriate authority.

Any breach of this provision is liable to a fine of Five Hundred Thousand Leones (Le. $500,000)$ and / or a term of Six (6) months imprisonment.

Section 15

It is an offence for any unauthorized person to move in or out of a quarantined area, or for any means of transportation (e.g. boats, lorries, cars or bikes) to enter or leave without the permission of the relevant authority.

Any breach of this provision is liable to a fine of up to Five Hundred Thousand Leones (Le. 500,000) and / or a term of Six (6) months imprisonment.

Section 16

All public places, including places of worship, mosques, churches, temples shall endeavor to have buckets with chlorinated water or soap available for visitors and worshippers to wash their hands before entering.

Section 17

Any public official, including but not limited to officials of government, local government or chiefdom or law enforcement officers, who impedes the application or enforcement of any of these Byelaws shall be guilty of an offence Any breach of this provision is liable to a fine of Five Hundred Thousand Leones (Le. $500,000)$ and / or a term of Six (6) months imprisonment, and the official shall be reported to the appropriate authority. 
Section 18

All Paramount Chiefs, Section Chiefs, Sub-Chiefs, Town Chiefs, Village Chiefs and their Speakers shall ensure strict compliance with the provisions of these Byelaws within their locality.

Any chief who has been found negligent in the application and enforcement of these Byelaws is liable to a fine of Five Hundred Thousand Leones (Le. 500,000) and / or summary suspension from office.

Section 19

Notwithstanding the fines and other punishment set out for offences under these Byelaws, chiefdom authorities retain the right to pursue legal action in the Local Courts or courts of higher jurisdiction, for flagrant violations of these Bye laws.

Signed this 11th day of August 2014

Hon. Finda Diana Konomanyi Kabba

Minister of Local Government \& Rural Development

P.C. Charles Caulker, Chairman

National Council of Paramount Chiefs 


\section{References}

- Acemoglu, Daron, Tristan Reed, James Robinson. 2014. Chiefs: Economic Development and Elite Control of Civil Society in Sierra Leone. Journal of Political Economy 122(2): 319-68.

- Fang, Li-Qun, Yang Yang, Jia-Fu Jiang, Hong-Wu Yao, David Kargbo, Xin-Lou Li, Bao-Gui Jiang, Brima Kargbo, Yi-Gang Tong, Ya-Wei Wang, Kun Liu, Abdul Kamara, Foday Dafae, Alex Kanu, Rui-Ruo Jiang, Ye Sun, Ruo-Xi Sun, Wan-Jun Chen, MaiJuan Ma, Natalie E. Dean, Harold Thomas, Ira M. Longini, M. Elizabeth Halloran, WuChun Cao. 2016. Transmission Dynamics of Ebola Virus Disease and Intervention Effectiveness in Sierra Leone. Proceedings of the National Academy of Sciences 113(16): 4488-93.

- NPS 2007. National Public Survey, Institutional Reform and Capacity Building Project, Sierra Leone. https://doi.org/10.7910/DVN/E3AOFV.

- Nunn, Nathan, Diego Puga. 2012. Ruggedness: The Blessing of Bad Geography in Africa. Review of Economics and Statistics, 94, 20-36.

- Richards, Paul, Joseph Amara, Mariane C. Ferme, Prince Kamara, Esther Mokuwa, Amara Idara Sheriff, Roland Suluku, Maarten Voors. 2015. Social Pathways for Ebola Virus Disease in Rural Sierra Leone, and Some Implications for Containment. PLoS Neglected Tropical Diseases 9(1): 15.

- Riley, Shawn J., Stephen Daniel Degloria and D.S. Elliot (1999) A Terrain Ruggedness Index that Quantifies Topographic Heterogeneity, Intermountain Journal of Sciences, 5(1-4): $23-27$

- USGS. 2006. Shuttle Radar Topography Mission, 30 Arc second scene 2.0. Global Land Cover Facility, University of Maryland, College Park, Maryland. 